\title{
Seasonal Variations in Cataract Surgery Numbers in Mid Western and Far Western Terrain Belts of Nepal
}

\author{
Bastola $\mathrm{P}^{1}$, Bascaran $\mathrm{C}^{2}$, Foster $\mathrm{A}^{3}$
}

\begin{abstract}
Introduction: In western regions of Nepal many more cataract operations are performed during the winter season than the summer season. This causes problems with resource allocation. The aim of this study was to assess the magnitude of seasonal variation in cataract surgery, explore the causes, and make recommendations to optimize resource utilization. Methods: Hospital data of the number of patients undergoing cataract surgery in the years 2011, 2012 and 2013 in 3 hospitals was analyzed by month of surgery. 100 consecutive patients having cataract surgery in the winter season and 100 in the summer season were compared for differences and questioned as to the reasons for choosing cataract surgery at that time. Results: Of the 127,718 cataract operations performed over 3 years in the 3 hospitals, 45\% were performed in the 3 months February-April and $9 \%$ in the 3 months June-August. The mean number performed in March (highest volume month) was more than 7 times higher than that performed in July (lowest month) 8016 versus 1041 per month. At univariate level nationality, marital status, socioeconomic status, cost per surgery, occupation, age and ethnicity were associated with seasonal variations. Multivariate logistic regression analysis of seasonal uptake showed Nationality/Ethnicity, Socioeconomic status and cost per surgery statistically significant in predicting attendance in high season. Conclusions: There is a large seasonal variation in cataract surgery numbers in West Nepal. Factors including patients' nationality cost of surgery and cultural beliefs contribute to the seasonal variation. If these can be addressed then resource allocation and utilization can be improved.
\end{abstract}

Key words: Cataract, Nepal, resource utilization, seasonal variation

\section{INTRODUCTION}

The total population of Mid and Far Western Regions (MWR + FWR) of Nepal is approximately 6.5 million people. The prevalence of blindness (Corrected visual acuity in the better eye less than $3 / 60$ or visual fields less than 10 degrees is defined as blindness in Nepal and is a World Health Organization definition as well) in MWR/FWR is $0.23 \%$ and $0.41 \%$ respectively (Mean $0.32 \%$ ) giving an estimated 20,000 blind people of which $67 \%$ is due to cataract ${ }^{1}$.

Eye health care in MWR/FWR is primarily provided by the National Non Governmental Organization (NGO) Nepal Netra Jyoti Sangh (NNJS) with support from International Non Governmental Organizations (INGOs). Many patients from northern India come to Nepal for eye care services ${ }^{2,3}$.

1. Dr. Pradeep Bastola

2. Dr. C. Bascaran

3. Dr. A. Foster

Address for correspondence:

Dr. Pradeep Bastola

Department of Ophthalmology

Nepalgunj Medical College Teaching Hospital

Kohalpur, Banke, Nepal

E-mail: pbs_dinku@yahoo.com, drbastola15@gmail.com
Recent data from NNJS indicate that people from India contribute more than $55 \%$ of total number of cataract surgeries done in Nepal ${ }^{4}$. The observation that more than half of the annual cataract operations are operated in a four month winter / high season caussing difficulties with planning the allocation of resources, particularly cataract surgical teams ${ }^{4}$. If the demand for cataract surgery could be more equally distributed this could improve the efficiency and possibly the quality of cataract service delivery and better resource utilization in the hospital.

The factors associated with seasonal variation in Nepal have not been studied scientifically. The study thus primarily focused in finding out the magnitude of seasonal variation in cataract surgeries, explore the causes and make recommendations to combat the problem

\section{MATERIALS AND METHODS}

Records from three hospitals (Nepalgunj, Fateh Bal and Geta Eye Hospitals), for the years 2011, 2012 and 2013 were analyzed to document the number of cataract operations performed each month.These all study hospitals offer similar prices for the cataract surgery. The base eye hospital (Geta Eye Hospital) and Fateh Bal Eye Hospital are under the roof of NNJS, while Nepalgunj Eye Hospital is a private eye hospital with tertiary level services in Mid Western plain belt. Ethical 
approval for the study was obtained from London School of Hygiene and Tropical Medicine (LSHTM), London, and the Institutional Review Board (IRB) of Nepal Netra Jyoti Sangh, Nepal. All the participants were given written and verbal information about the study, and informed consent was obtained from the participants.

Hundred consecutive patients undergoing surgery for agerelated cataract in the high volume winter season and 100 patients in the low / summer season were identified and a standard questionnaire was completed to document various demographic and socio-economic factors. The two groups of patients were also questioned as to the reason for attending in high / winter or low / summer season. Hindus were also kept in ethnic groups with a common agreement that, religiously also they are Hindus. Data was collected, entered in Microsoft excel, and analyzed using Stata version 13. A statistician was consulted when necessary.

\section{RESULTS}

A total of 127,718 cataract operations were performed in the 3 hospitals over the period 2011- 2013. The magnitude of seasonal variation was similar in all 3 study hospitals Figure 1). Comparison of the socio-demographic variables in 100 patients questioned in the high/winter season and 100 in the low/summer season is summarized in Tables I and II.

In the high season $92 \%$ of patients were from India compared with $69 \%$ in the low season; and $79 \%$ were from middle to high socio-economic strata compared with $36 \%$ in summer. Patients in winter were more likely to be married, male gender and older than those coming in summer. Housewives $16 \%$ preferred the winter season where as self employed patients $12 \%$ preferred the summer season occupation wise. Despite being from higher socio-economic strata people attending in the high winter season paid less for cataract surgery than those in low summer season $-99 \%$ of patients paid $<1500$ Nepali Rupees (NRs) in the high season compared with $80 \%$ of patients paying 2000NRs or more in the low season.

At univariate level nationality, ethnicity, occupation, cost per surgery, socioeconomic status, marital status, age were associated with seasonal variations (Table I, II).

When Multvariable logistic regression analysis of seasonal uptake was undertaken using the dependent binary variable High Season Attendee and the independent predictor variables significant at the univariate level - Age, Nationality, Ethnicity, Marital Status, Occupation, Socioeconomic Status and Cost of Surgery. Nationality and Ethnicity were combined into one variable due to their interactive properties.

Holding all other factors constant, only Nationality/ethnicity, Socio-Economic Status and Cost of Surgery were statistically significant factors in predicting attendance in high season
(Table III). When questioned as to why patients came in the high or low season, 54\% of patients attending in the high/winter season said that it was because surgery was safer in winter; while those attending in the low/summer season, $51 \%$ said it was because of diminished vision Figure 2 ).

\section{DISCUSSION}

Cataracts are the major cause of blindness and visual impairment in developing countries and contribute to more than $90 \%$ of the total disability adjusted life years ${ }^{5}$. There have been various studies focussed on the prevalence of cataract and cataract blinds ${ }^{1}$, barriers to uptake cataract surgeries ${ }^{1}$, the global burden of cataract ${ }^{5}$, the modern methods of cataract surgeries including femtosecond laser cataract surgery specially in developed world ${ }^{6}$. However there have not been significant studies about the seasonal variation in cataract surgery till now specially in developing countries where the prevalence of cataract and cataract blinds is very high ${ }^{1,4}$. Seasonal variation in cataract surgery numbers has remained a significant problem in a poor developing nation like Nepal. Where eye health system runs parallel to the general health system $^{1,4}$.

The study clearly demonstrates a consistent seasonal variation in cataract surgery numbers over the last 3 years in 3 independent hospitals. The observation that there is a 7 fold variation in monthly numbers between the busiest and least busy months demonstrates the problem of planning resources for good service provision.

The main differences seen in the high/winter season and low/summer season patients was Indian nationality, higher socio-economic strata and need to pay less for surgery in the high/winter season. Patients attending in high season were significantly far less likely to be Nepali (of any ethnic denomination) than Indian Hindu ( $\mathrm{OR}=0.004,95 \% \mathrm{Cl}=0.00-0.9$, $p=0.00$ ). Patients were also less likely to be Indian Brahmin or Indian Muslim than Indian Hindu, but this was not significant (Table III).

Patients in the high winter season were seven times more likely to be middle or high income than low income (OR=7.3, $95 \% \mathrm{Cl}=1.3-41.5, \mathrm{p}=0.03)$. Despite the higher proportion of middle or high income patients in winter, $99 \%$ of surgeries in high season were conducted either free or subsidized compared with $20 \%$ of those in low season, leading to an extremely low odds ratio of paying in full in high season compared with low season $(\mathrm{OR}=0.0002,95 \% \mathrm{Cl}=0.0-0.004$, $\mathrm{p}=0.00$ ). The overall model was statistically significant and explained $84 \%$ of the variability by season (McFadden's $\mathrm{R} 2=0.84, \mathrm{p}=0.00)$ (Table 3).

The main reason for attendance in the low/summer season was diminished vision (51\%); $61 \%$ of these patients were from lower socioeconomic strata and $16 \%$ of the summer study 


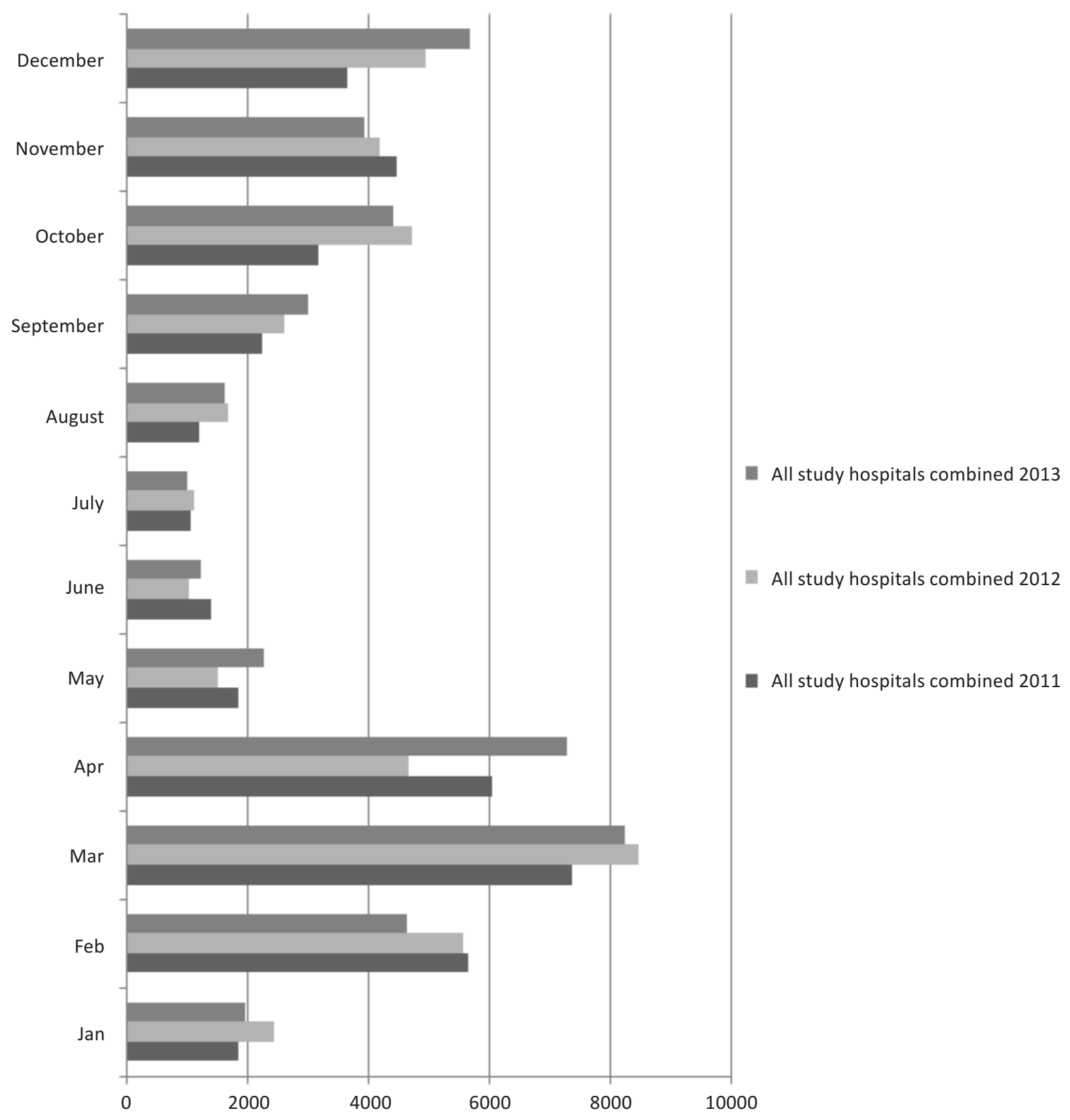

Figure 1: Cataract operations by year and month in 3 Nepali hospitals, 2011-2013.

sample thought the cost per surgery during the summer season is cheaper. However interesting fact which came out from the 200 study subjects of both the seasons was; $99 \%$ of the patients in the winter summer season sample were operated in cheaper prices either subsidized or free of cost. all patients coming in the high and low seasons, however the study has revealed some interesting information which can be tested to see if people can be persuaded to come in the low / summer season rather that the high / winter season.

Caution is required in analyzing the data as the 100 patients questioned in summer and winter may not be representative of 


\begin{tabular}{|c|c|c|c|}
\hline Variable & $\begin{array}{c}\text { High winter season } \\
\text { (100 subjects) }\end{array}$ & $\begin{array}{c}\text { Low summer season } \\
\text { (100 subjects) }\end{array}$ & $p$ value \\
\hline \multicolumn{4}{|l|}{ Gender } \\
\hline Male & 56 & 43 & \multirow{2}{*}{$\begin{array}{c}0.089 \\
\text { Fisher exact test }\end{array}$} \\
\hline Female & 44 & 57 & \\
\hline \multicolumn{4}{|l|}{ Age in years } \\
\hline Median & 60 & 60 & \multirow{2}{*}{$\begin{array}{c}0.0003 \\
\text { Wilcoxon rank-sum }\end{array}$} \\
\hline Interquartile range & $60-65$ & $50-65$ & \\
\hline \multicolumn{4}{|l|}{ Nationality } \\
\hline Nepali & 8 & 31 & \multirow{2}{*}{$\begin{array}{c}<0.001 \\
\text { Fisher exact test }\end{array}$} \\
\hline Indian & 92 & 69 & \\
\hline \multicolumn{4}{|l|}{ Ethnicity } \\
\hline Brahmin & 9 & 43 & \multirow{8}{*}{$\begin{array}{c}<0.001 \\
\text { Fisher exact test }\end{array}$} \\
\hline Tharu & 2 & 19 & \\
\hline Chhetri & 17 & 3 & \\
\hline Magar & 0 & 1 & \\
\hline Muslim & 17 & 7 & \\
\hline Vaishya & 7 & 16 & \\
\hline Thakuri & 6 & 1 & \\
\hline Hindu & 42 & 10 & \\
\hline \multicolumn{4}{|l|}{ Marital Status } \\
\hline Married & 99 & 78 & \multirow{3}{*}{$\begin{array}{c}<0.001 \\
\text { Fisher exact test }\end{array}$} \\
\hline Widowed & 0 & 21 & \\
\hline Never married & 1 & 1 & \\
\hline \multicolumn{4}{|l|}{ Occupation } \\
\hline Agriculture & 73 & 74 & \multirow{6}{*}{$\begin{array}{c}0.005 \\
\text { Fisher exact test }\end{array}$} \\
\hline Government job & 2 & 4 & \\
\hline Housewife & 16 & 6 & \\
\hline Business & 7 & 3 & \\
\hline Priest & 0 & 1 & \\
\hline Self employed & 2 & 12 & \\
\hline \multicolumn{4}{|c|}{ Socioeconomic status } \\
\hline Below poverty line & 0 & 20 & \multirow{4}{*}{$\begin{array}{c}<0.001 \\
\text { Fisher exact test }\end{array}$} \\
\hline Low income & 21 & 41 & \\
\hline Middle income & 77 & 36 & \\
\hline High income & 2 & 0 & \\
\hline \multicolumn{4}{|l|}{ Education } \\
\hline No education & 78 & 78 & \multirow{4}{*}{$\begin{array}{c}0.79 \\
\text { Fisher exact test }\end{array}$} \\
\hline Primary level & 6 & 8 & \\
\hline Secondary level & 9 & 10 & \\
\hline College level+ & 7 & 4 & \\
\hline \multicolumn{4}{|l|}{ Residence } \\
\hline Remote rural & 2 & 0 & \multirow{4}{*}{$\begin{array}{c}0.41 \\
\text { Fisher exact test }\end{array}$} \\
\hline Rural & 82 & 89 & \\
\hline Semi urban & 4 & 3 & \\
\hline Urban & 12 & 8 & \\
\hline
\end{tabular}

Table I: Comparison of socio-demographic variables in people having cataract surgery in the high/winter and low/summer seasons in 3 Nepali hospitals in 2014 


\begin{tabular}{|c|c|c|c|}
\hline \multicolumn{4}{|l|}{ Type of Surgery } \\
\hline SICS & 100 & 95 & \multirow{3}{*}{$\begin{array}{c}0.059 \\
\text { Fisher exact test }\end{array}$} \\
\hline Phacoemulsification & 0 & 4 & \\
\hline Other & & 1 & \\
\hline \multicolumn{4}{|c|}{ Post operative visual acuity (VA) } \\
\hline Good & 60 & 65 & \multirow{3}{*}{$\begin{array}{c}0.64 \\
\text { Wilcoxon rank-sum }\end{array}$} \\
\hline Borderline & 37 & 28 & \\
\hline Poor & 3 & 7 & \\
\hline \multicolumn{4}{|l|}{ Cost per surgery } \\
\hline Free of cost & 1 & 20 & \multirow{6}{*}{$\begin{array}{c}<0.001 \\
\text { Wilcoxon rank-sum }\end{array}$} \\
\hline$<1500$ NRS & 98 & 0 & \\
\hline $1600-2000$ NRS & 1 & 0 & \\
\hline $2100-3500$ NRS & 0 & 75 & \\
\hline $5000-6500$ NRS & 0 & 4 & \\
\hline Other & 0 & 1 & \\
\hline \multicolumn{4}{|l|}{ Health Insurance } \\
\hline Yes & 0 & 1 & \multirow{2}{*}{$\begin{array}{c}0.5 \\
\text { Fisher exact test }\end{array}$} \\
\hline No & 100 & 99 & \\
\hline
\end{tabular}

Table II: Comparison of variables related to the operation of people having cataract surgery in the high / winter and low / summer seasons in $\mathbf{3}$ Nepali hospitals in 2014

\begin{tabular}{|c|c|c|c|c|}
\hline \multicolumn{4}{|c|}{ Multivariable Logistic Regression of Predictors of High Season Attendance } & \multirow[b]{2}{*}{$\mathbf{p}>\mathbf{z}$} \\
\hline & $\begin{array}{c}\text { Low Season } \\
\text { Attendees }(n=100)\end{array}$ & $\begin{array}{c}\text { High Season } \\
\text { Attendees }(n=100)\end{array}$ & Odds Ratio (95\% Cl) & \\
\hline \multicolumn{5}{|l|}{ Age Group } \\
\hline$<65$ & $74 \%$ & $60 \%$ & Baseline & - \\
\hline$>65$ & $26 \%$ & $40 \%$ & $1.49(0.3-8.2)$ & 0.6 \\
\hline \multicolumn{5}{|l|}{ Nationality/Ethinicity } \\
\hline Indian Hindu & $9 \%$ & $37 \%$ & Baseline & - \\
\hline Indian Brahmin & $34 \%$ & $9 \%$ & $0.26(0.004-15.4)$ & 0.5 \\
\hline Indian Muslim & $7 \%$ & $17 \%$ & $0.85(0.008-88.4)$ & 0.9 \\
\hline Indian Other & $19 \%$ & $29 \%$ & $0.34(0.008-14.2)$ & 0.6 \\
\hline Nepalese & $31 \%$ & $8 \%$ & $0.004(0.0002-0.1)$ & 0.00 \\
\hline \multicolumn{5}{|l|}{ Socioeconomic Status } \\
\hline Below poverty line or low income & $61 \%$ & $21 \%$ & Baseline & - \\
\hline Middle or High Income & $39 \%$ & $79 \%$ & $7.3(0.03-41.5)$ & 0.03 \\
\hline \multicolumn{5}{|l|}{ Occupation } \\
\hline Agriculture & $74 \%$ & $73 \%$ & $0.2(0.004-11.4)$ & 0.4 \\
\hline Housewife & $6 \%$ & $16 \%$ & Baseline & - \\
\hline Other & $20 \%$ & $11 \%$ & $0.2(0.001-26.0)$ & 0.5 \\
\hline \multicolumn{5}{|l|}{ Cost } \\
\hline Free or Subsidized & $20 \%$ & $99 \%$ & Baseline & - \\
\hline Paid in full & $80 \%$ & $1 \%$ & $0.0002(0.0000-0.004)$ & 0.00 \\
\hline \multicolumn{5}{|l|}{ Marital Status } \\
\hline Married & $78 \%$ & $99 \%$ & Baseline & - \\
\hline Never married or widowed & $22 \%$ & $1 \%$ & $0.2(0.002-9.7)$ & 0.4 \\
\hline
\end{tabular}

Table III: Multivariable Logistic Regression of Predictors of High Season Attendance 

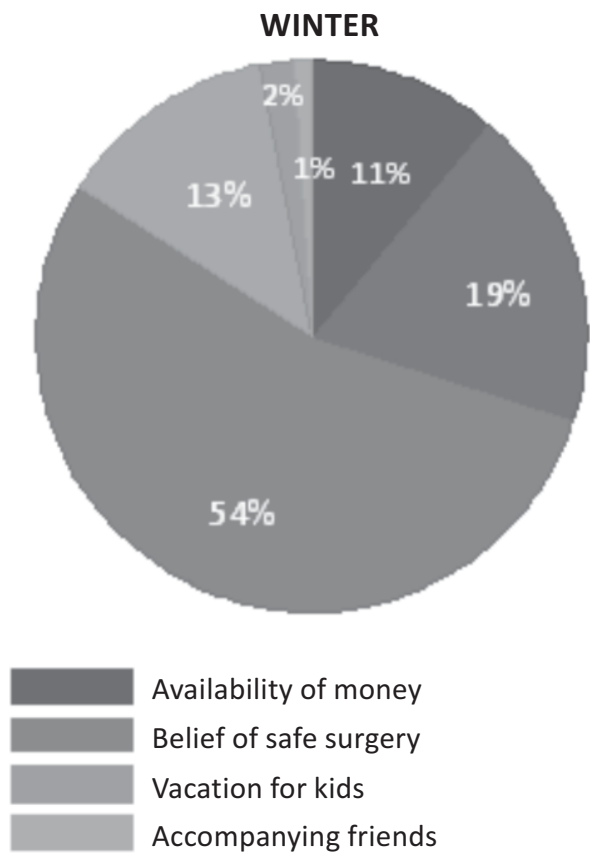

Availability of money

Belief of safe surgery

Vacation for kids

Accompanying friends
SUMMER

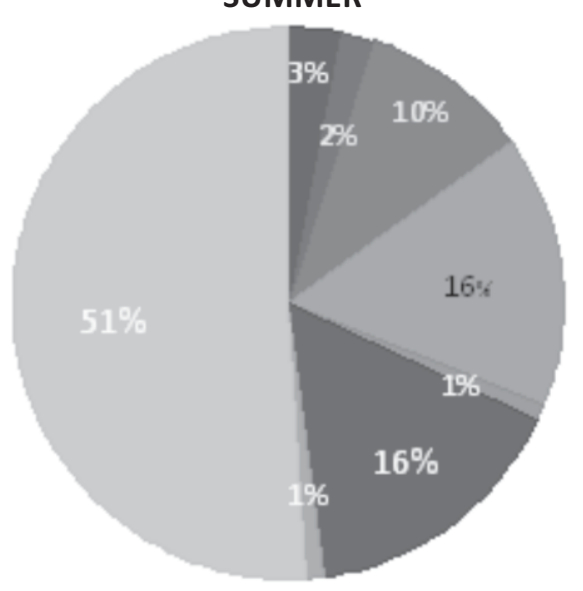

Post harvesting/good outcome

Good outcome in fellow eye

Cheaper due to charities

Diminished vision

\section{Graphs by season}

Figure 2 clearly showing belief for surgery was the main reason for patient attendance during winter, while in summer diminished vision was the main reason for the patient for attending the hospitals.

\section{CONCLUSIONS/RECOMMENDATIONS}

It is recommended that the cost of surgery in high/winter be increased or at least equal to the summer cost of the surgery. The free hospital based camps or subsidized surgeries should be encouraged to be done in the summer season more; as the study sample finding could conclude that; the cost per surgery during the winter season is currently lower than the summer season probably due to more charities and funding coming in the winter season.

Most people coming in the winter season are from middle to high socio-economic strata. An increase in price in the winter season or focusing more on subsidized or free surgery during the summer season should not be a barrier to access for cataract surgery but should encourage patients in some shift in choice of seasons. Also consideration should be given to only operating on first eyes in the high/winter season and asking people who want operation on their second eye to come in summer.

As with any policy and behavior change it will be important to inform both providers and patients of why current policy and practice is being changed.

\section{ACKNOWLEDGEMENTS}

We would like to acknowledge Nepal Netra Jyoti Sangh (NNJS), Nepal and London School of Hygiene and Tropical Medicine, London, United Kingdom for providing an ethical approval letter to carry out the study. We would like to acknowledge all the patients and study eye hospitals for their kind cooperation. We would like to acknowledge Dr. Catey Bunce and Dr. Islay Mactaggart for the statistical analysis. In the mean time, we would like to acknowledge Dr. Bidya Pant and Dr. Suresh Pant, Geta Eye Hospital for providing information and giving correct data from the hospital.

Finally, we would like to acknowledge Professor Clare Gilbert for her invaluable suggestions.

\section{REFERENCES}

1. Sapkota YD, Limburg H. The Epidemiology of Blindness in Nepal: 2012. ISBN number: 978-993702-5467-0. (Cited 2013, D e c e m b e r) a a i la ble o n I i n e : http://nnjs.org.np/resources/show/Publication

2. Nepal Red Cross Society. Community Empowerment Health Promotion Program (CEHP). Annual Progress Report 2012. January-December. (Cited 2013, November) available online : http://www.nrcscehp.org/reports/rep_main.htm

3. Brilliant LB, Pokhrel RP, Grasset NC, Lepkowski JM, Kolstad A, Hawks W, et al. Epidemiology of blindness in Nepal. Bulletin of the world health organisation. 1985;63(2):375-86

4. Mid-term review of vision 2020: The Right to Sight, Nepal 2011. Apex Body for Health, Ministry of Health and Population, Government of Nepal, Ramshahpath, Kathmandu, 2011.

5. Rao GN, Khanna R, Payal A. The global burden of cataract. Curr Opi Ophthalmol 2011;22(1):4-9.

6. Bastola P, Dick BH. An experience of femtosecond laser assisted cataract surgery in advanced brown cataracts in a tertiary Eye Center of Europe. Nepal Journal of Medical Sciences 2013;2(2):114-8. 